\title{
30 \\ RUSSIA \\ Russian pendulum: From glorious science propaganda to modest public engagement initiatives
}

\author{
Alexandra Borissova and Dmitry Malkov
}

\section{Introduction}

In 2017, Russia commemorated 100 years since the October revolution. As a matter of convenience, in this chapter we stick to the same time frame by summarising 100 years of evolution of modern science communication in Russia, from the space race-era science propaganda to the present-day Westernised approach. Not coincidentally, this evolution closely followed the train of political and ideological thought in the country, thus drawing a visible line between Russia and other world regions. To help our readers, we will highlight several historic periods unified by the same way of thinking about science communication. Throughout the chapter we will resort to different terminology to refer to science communication. Until quite recently, the prevailing term used to describe the field in Russia has been 'science popularisation', rather than communication. This heritage is still quite noticeable as the term enjoys widespread usage by the community and state officials. Even such terms as 'science propaganda' and 'enlightenment' have been somehow preserved and are used today. 'Science communication' is a relatively new term in Russia and was introduced to refer to public communication of science as a separate profession around 2010. This name is not as widely used by practitioners, but a growing number of people recognise it as a unifying term for both the professional field and the rising academic discipline of the same name. We do not plan to elaborate further on terminology but will attempt to trace the conceptual evolution of the field. 


\section{2. 'We will go another way' (1917-91)}

The headline quote, attributed to Vladimir Lenin (in fact, it belongs to the poet Vladimir Mayakovsky), not only perfectly reflects the Soviet path in general, but also the development of science and science communication during the communist period. The objectives of science communication, or rather science propaganda as it was referred to at the time, were entirely politically driven. The young Soviet state proclaimed priority tasks of modernisation, industrialisation and urbanisation of the largely rural and illiterate country. Patriotic slogans declared the tsarist past to be scientifically backward, while the socialist future was seen as radiant and technologically advanced (Andrews, 2003). Therefore, alongside unprecedented strengthening of formal education (known as likbez, i.e. 'elimination of illiteracy'), massive efforts were made to introduce what is now known as informal science education or science popularisation. Implemented on the federal level, these programs enjoyed huge centralised support both politically and financially. This awareness was only reinforced by the Cold War as the Soviet Union strived to demonstrate its scientific and technological superiority over the United States and other countries.

Science propaganda via public lectures and discussions in the Soviet Union had an unimaginable reach by modern-day Russian standards, or by any standards for that matter. One of the flagships of this activity was the Znanie Society [Knowledge Society]. Signed into existence by Joseph Stalin in 1947 (Litvak, 2008), it was commissioned with the popularisation of scientific and political ideas - a combination that testifies to the predominantly political purpose of the Soviet-style science popularisation. By the 1970s, the society organised a variety of public lectures, themed nights, radio and television broadcasts and produced popular science films. In 1976 alone, the members of the society conducted more than 24 million public lectures (Nauka i Zhizn, 1977). The logic of the Soviet state assumed that every citizen had to undergo continuing education for the sake of the national economy and communism. Another example of the whopping outreach of the Znanie Society is the Soviet weekly newspaper Argumenty i Fakty [Arguments and Facts], which belonged to the society. In 1990, the newspaper entered the Guinness Book of Records for the largest weekly newspaper circulation in human history, namely 33.5 million copies (Fishman, 2005, p. 194). 


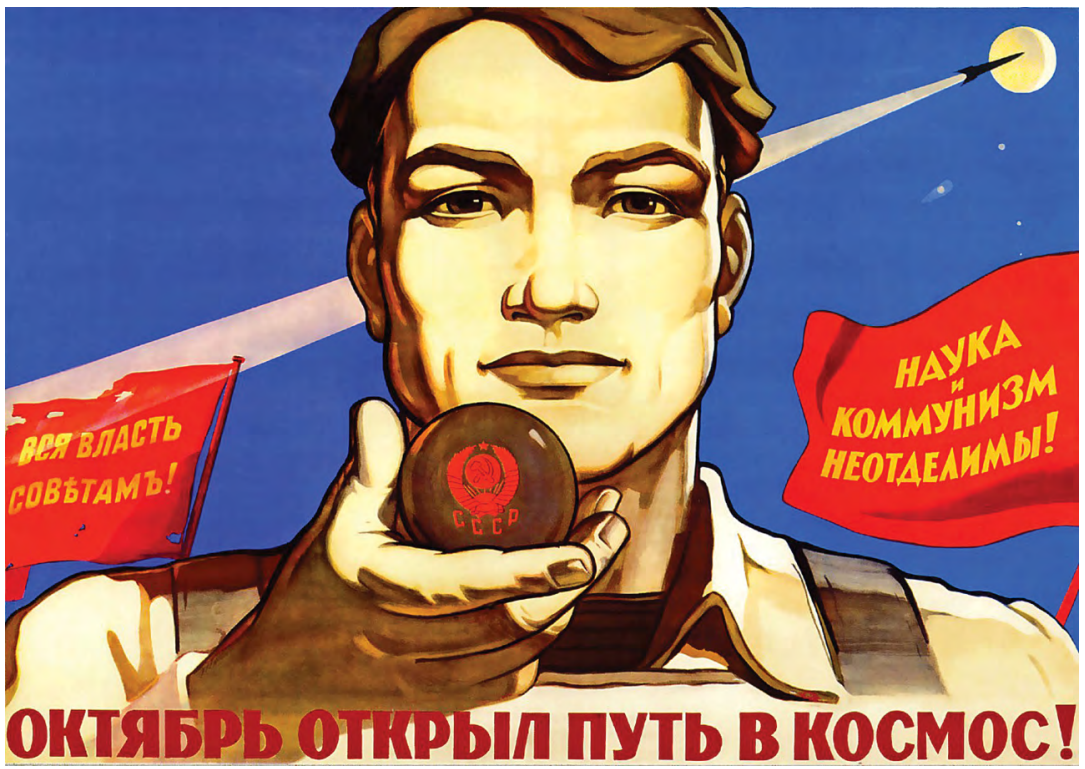

Figure 30.1: One of many Soviet posters used to promote science. The messages on the poster testify to the political roots of popular science of that era: 'Science and communism are inseparable!' and 'October revolution opened pathway to space!'.

Source: Public domain (softsalo.com/sovet_45_poli/poli_53.html).

Science magazines also enjoyed extremely high circulations. The oldest and most prominent Russian science magazine is Nauka i Zhizn [Science and Life]. Founded in 1890, it promptly became one of the foremost popular science magazines in Soviet times and grew from a 16-page weekly digest to a monthly 64-page edition with a circulation of around 3.5 million copies in the 1960s-80s (Yakovenko, 2012). The magazine was, of course, politicised-its long-term vice editor-in-chief was Rada Adzhubey, daughter of Nikita Khrushchev, the First Secretary of the Communist Party, 1953-64. Apart from Nauka i Zhizn, this stage was also championed by Znanie - Sila [Knowledge is Power] with 700,000 print copies distributed monthly and Khimiya $i$ Zhizn [Chemistry and Life] with 300,000 monthly copies. About a dozen other titles were widespread and could be found in any household. Conceived and perceived as a form of leisure for the entire family, these magazines often contained crosswords, food recipes and other information, which today we might deem irrelevant to science. Although they provided facts and figures, these periodicals suffered from the lack or even complete absence of any critical view or investigative journalism, as well as selfinflicted isolationism. Naturally, discussions about science policy were off the table entirely. 
The immense circulations exercised by big popular science magazines required a large intellectual work force. Consistent science journalism education was not yet in place, but several schools did prepare science writers. Perhaps the most prominent and longest living science journalism studio was created early in the 1980s by the Khimiya i Zhizn magazine. Its target audience was mainly science and engineering students who gathered occasionally to test their science writing skills, discuss texts and sometimes just play the guitar. With time the science journalism studio became a unique source of writers for Khimiya i Zhizn and similar magazines.

Science was a subject of motion movies and TV programs. The flagship was Ochevidnoe-neveroyatnoe [Obvious-unbelievable], started in 1973 by a prominent Russian scientist and populariser Sergey Kapitsa. A son of the Nobel laureate physicist Pyotr Kapitsa and distinguished physicist himself, Sergey Kapitsa suffered from the Sagan effect ${ }^{1}$ during his research career due to his public activity. Various sources report high officials from the USSR Academy openly telling his father that Sergey would not be elected to the Academy if he started a TV show. He was, indeed, never elected. Nevertheless, his TV program lasted for decades until his death in 2012, and Kapitsa Jr remains an icon of the modern-day science engagement in Russia (Borisova and Malkov, 2018).

Other forms of science popularisation kept pace. Science and technology museums were built as far as the eye could see to commemorate the glory of the Soviet technological progress. A considerable number of the 245 natural history museums and around 100 science museums we know today were built in the Soviet period (Russian Venture Company, 2016). Not surprisingly, more than half the science and technology museums were aerospace museums, a tribute to the country's historical developments in space exploration. Museums such as the Moscow Polytechnic Museum and the Memorial Museum of Cosmonautics were crown jewels of Soviet science propaganda, underpinned by the one-party system and fierce political support.

In parallel to these broad propaganda efforts, another way of thinking proliferated in Soviet society. Some scholars argue (Kukulin, 2017) that the seeds of the 'new age' thinking and various sorts of occultism were planted through popular science magazines of the Soviet era that freely published articles about paranormal phenomena, UFOs and other ideas of this kind alongside scientific pieces. Beliefs such as those of ancient astronauts started

1 The Sagan effect can be defined in various ways. One of these versions states that the scientific popularity of a scientist with the general public is considered to be inversely proportional to the quality and quantity of that scientist's scientific work (Baldscientist, 2013). 
to spread from academic circles with both natural scientists and humanities scholars involved (Panchenko, 2018) and reached the audience of engineers and other parts of so-called Soviet intelligentsia.

\section{Back to square one (1991-2001)}

With the collapse of the Soviet Union at the beginning of the 1990s, the popularisation of science plummeted together with science itself. The grave economic situation (Milanovich, 1998) led to dwindling science funding and left virtually no room for any institutional support of science communication. In 1992, the total expenditures on science from all sources halved. By 1994 science funding in Russia as a share of GDP was about one-sixth of that of developed Western countries (Graham and Dezhina, 2008). Science and technology propaganda came to be perceived by the population as manipulative and patronising. With the influx of freedom in the 1990s, new age thinking spread from white-collar circles to a broader, less educated audience. Hence, the arrival of the 1990s meant a dramatic shift from the national dissemination of science towards other forms of leisure and interest areas. Foreign literature on culture, philosophy and spirituality cracked through the restrictions imposed by the Soviet government. Science was no longer appealing to the population and the country submerged in mysticism and obscurantism that still can be tracked in the modern Russia.

Under these circumstances, science communication naturally fell low in the list of priorities. While many Western countries were busy elaborating on novel approaches to science communication, including dialogue and participatory engagement models, there were no significant developments in this area in 1990s Russia whatsoever. Activities such as public lectures endured, of course, but their content switched to philosophy and humanities. The celebrated Auditorium of the Moscow Polytechnic Museum, which once hosted scientific luminaries such as Ilya Mechnikov or Niels Bohr, was now rented for public events on anything but science and technology. The Znanie Society crumbled and popular science lectures virtually disappeared. The society was partly brought back to life in 2015 under the Russian Ministry of Science and Higher Education, but it never came close to its past Soviet grandeur (State Legal Information System, 2015).

The fate of the once flourishing landscape of popular science magazines is documented in the history of the Nauka i Zhizn magazine. Once an icon of the Soviet Union with a circulation of millions of copies monthly, the magazine was reduced to a thick 144-page monthly edition and a circulation of 36,000 copies. Nauka i Zhizn managed to survive throughout the 1990s, 
but the print version never fully recovered. Later in the digital age, its online version managed to become one of the busiest in the market with a monthly audience of over 750,000 unique visitors (Rambler Top 100, n.d.). This case is quite unusual, however, as the vast majority of titles simply ceased to exist in the 1990s and never came back. What used to be a rich market in the USSR is barely a market at all in modern Russia (Yakovenko, 2012). Indeed, today there are print magazines with similar content, but there remain no strong players who are able to compete. Consequently, these print editions have been reduced to a niche product for a specific science-oriented audience and have lost their outstanding public role.

As the Russian economy started to recover after the default of 1998, some developments did occur in the late 1990s against the background of apathy towards science and science popularisation. For example, in 1998, Khimiya $i$ Zhizn launched a news agency called InformNauka, which aimed at disseminating Russian science both within and beyond the country. To supply the agency with science writers, Khimiya $i$ Zhizn relaunched its school of science journalism. The school was terminated in 2008, once management decided that they no longer needed to produce writers for the magazine and the agency, which itself was phased out a few years later. Several key radio programs also appeared at the end of this period. The oldest science program still active on the radio is Granit nauki [Granite of Science]. It started in 1997 as part of the then liberal radio station Echo of Moscow, which was owned by Gazprom-media. Radio Liberty in Russia also featured science in its programs since 1998, and later they strengthened this direction with their website broadcasts.

\section{Privatisation of science communication (2001-11)}

The situation slowly began to change around 2001. Irritated by the public contempt for science and the consequent rise in mysticism in Russia, several prominent figures stood up. Perhaps the most important of them was Dmitry Zimin, a Russian telecommunications tycoon with a profound respect for science, technology and education (Carnegie Medal for Philanthropy, 2013). Along with some other business owners, after the turbulent arrival of the market economy to the country, Dmitry Zimin adopted a more comprehensive model of corporate social responsibility. In 2001, he established the Dynasty Foundation, Russiass first private funder of science and science popularisation, which, among other things, began providing grant support to book publishing, science festivals, lectures and science museums. We will 
further focus on the activity of this foundation, as it was the first and for the larger part of its existence the only foundation of its kind in Russia and had an enormous impact both on science communication and philanthropy.

At first, the foundation focused on translating and publishing popular science books by foreign authors as Russian scientists at that time were not eager to engage in popularisation activities again. In fact, the academic community had come to despise this activity. The same was applicable to popular science lectures organised by the Dynasty Foundation in the early 2000s. Instead of inviting Russian scientists, the foundation mainly had to rely on foreign lecturers, frequently of significant calibre, such as various Nobel laureates (Dynasty Foundation, n.d.). Only by the mid-2000s did more Russian scientists begin to take up the role of public educators and lecturers. This allowed the foundation to organise entire science festivals (under the name Science Days) in all corners of the country. The Dynasty Foundation also introduced a variety of more relaxed and informal formats to Russia, i.e. science cafés. Most of the Dynasty-funded events were organised by enthusiasts and with little financial aid, but there is no doubt that the flow of private money throughout the 2000s helped popular science events and other activities regain some ground.

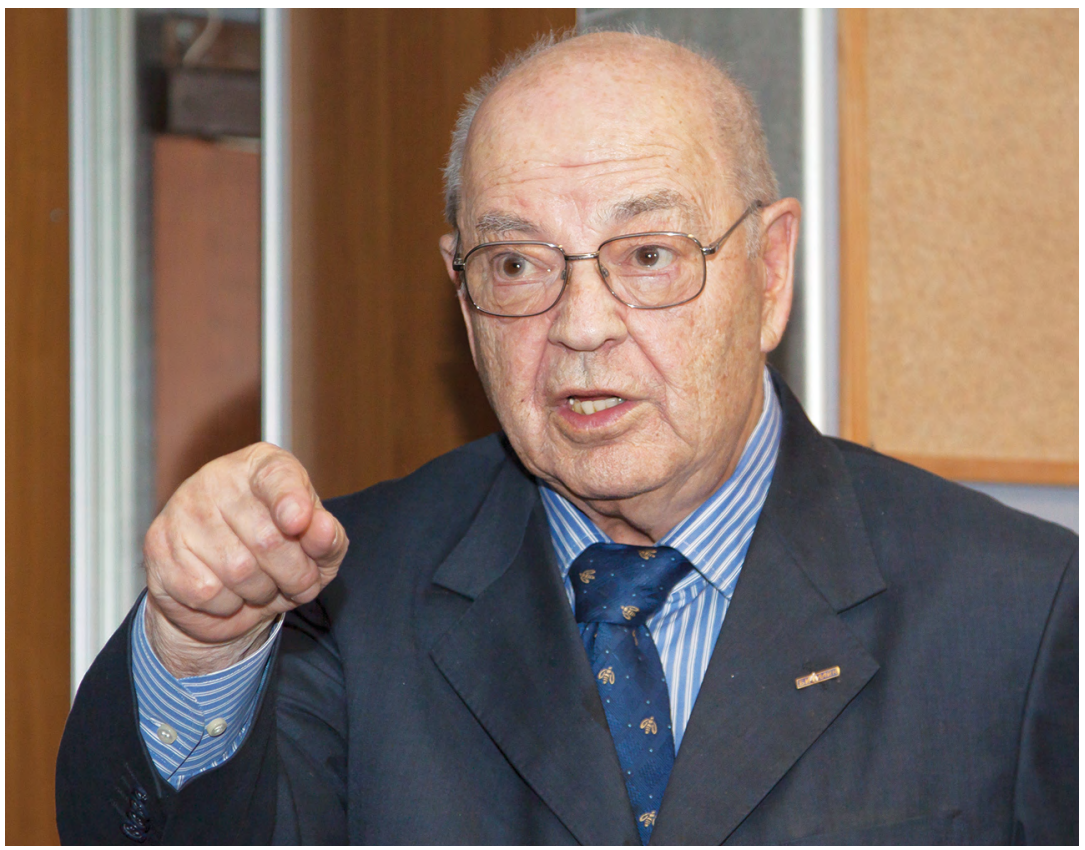

Figure 30.2: Dmitry Zimin, founder of the Dynasty Foundation.

Source: Maria Olendskaya (used with permission). 
Independently from the Dynasty Foundation, groundwork was being laid for the largest present-day popular science event in Russia-the All-Russian Festival of Science NAUKA 0+. As the story goes, the festival owes its existence to European science journalists, who during a visit to the Lomonosov Moscow State University in 2005 asked the rector why there was no large-scale science festival in Russia (Ria Novosti, 2013). The university decided to take the risk and so the idea of a new national science festival was born. The first edition in 2006 was a local popular science event attended by 20,000 people and it quickly paved the way for a city-wide event the next year. But the true nationwide expansion occurred only later, as we discuss in the next section.

Another area of science popularisation transformed with the help of the Dynasty Foundation was science museums and centres. From 2006 to 2014, the Dynasty Foundation conducted eight grant calls for regional museums, which summed up to about 150 million rubles in funding to 90 museum projects across Russia. The foundation also provided grant holders with international internship opportunities at the Copernicus Science Center in Warsaw, eventually attended by almost 30 directors of regional Russian science museums.

This grant program was run by Irina Aktuganova, one of the pioneers of the modern revival of Russian science museums. According to her, when the program was launched in 2006, science museums in Russia were in a state of hopeless stagnation. Conventional science museums merely survived. At the same time, the idea of a science centre was represented by solitary bottomup projects, such as the Experimentary in Irkutsk, which was created from scratch in 2005 by enthusiasts at the Siberian branch of the Russian Academy of Sciences. Curiously, it was inspired by the San Francisco Exploratorium. The idea of creating an interactive science centre occurred to the Russian biologist Konstantin Kravchenko when he visited the Exploratorium during his trip to the US in 1998 (Palshina, 2010). History repeated itself in 2012. After spending a year in San Francisco as a researcher, another young Russian scientist, Anton Sharypov, returned to his hometown of Krasnoyarsk (also in Siberia) to pursue the dream of creating his own science centre, Newtonpark (Burova, 2014). Given that back in the early 2000s, neither science museums nor science centres were of particular interest to anybody, the financial and expert support provided by the Dynasty Foundation made an invaluable contribution to the regrowth of the Russian science museum community.

Thanks to the Dynasty Foundation, the representation of researchers in the public domain - both politically and content-wise—expanded a great deal too. A popular science project called Elementy [Elements] got underway with foundation support in 2005. The website facilitated access to various resources that helped scientists get started with their non-academic writing. In 2008, 
another outlet called Troitsky variant - Nauka joined the Dynasty team as a political wing. Dubbed 'a newspaper of scientists and science journalists', it became (and in part remains) a place of vivid debate about science and education policy in Russia. Nearly everything became a subject of debate and criticism. As policymaking in the field of science suffered (or enjoyed, depending on the perspective) a great deal of change in the previous 25 years, Troitsky variant - Nauka provided mass media with a stable flux of stories (Graham and Dezhina, 2008).

While there were only a handful of dedicated science magazines, the 2000s was the era when science finally took off in general interest media outletsindependent, competitive and quickly growing in readership. Weekly magazines of political or business profiles were perhaps among the leaders in the popular science market during this period. Such periodicals as SmartMoney, The New Times, Itogi and Russian Newsweek featured elaborate science sections, produced by reporters with a predominantly scientific background. However, this did not last long as they fell victim to the paper press crisis in 2008-09 and, from 2012, they all were shut down, while the vast majority of authors left science journalism for good. Daily newspapers followed a similar trend. In 2000-06, Pleiades Publishing - a publisher of English translations of Russian scientific journals-ran a science communication project in the general interest media. According to its vice director-general, Nikolay Avanesov, the company financed the weekly supplements to Literaturnaya gazeta [Literary Newspaper], Izvestiya [News], Parlamentskaya gazeta [Parliamentary Newspaper] and Rossiyskaya gazeta [Russian Newspaper] that were dedicated to science, medicine and education.

When funding for this project came to an end, these outlets did not manifest independent interest in covering science. Science and technology sections were the first to be cut under economic pressures. At the same time, entire newspapers were being urged to go digital, but in online mode they had to compete with a new type of media-online newspapers. Three key players in this market were Gazeta.ru, Lenta.ru and Polit.ru, all of them founded from scratch as purely online media outlets in 1998-99 (Sapun, 2016). Their designated science sections appeared about five to six years after their creation, and survive to this day. The internet enjoyed the best of editorial freedom, and these outlets became a real school for a number of reporters who later created independent projects that shape contemporary Russian science journalism to a great extent.

Another important development during this period was the creation and growth of organised civil society groups related to science. Among the very first and most prominent is the Commission on Pseudoscience and Research Fraud, established in 1998 by the Russian physicist and Nobel laureate Vitaly 
Ginzburg. The commission provided recommendations concerning arbitrary scientific issues and publicly criticised pseudoscience and paranormal beliefs. Another society called the Science Journalist's Club was founded in 2004 and brought together nearly all science popularisers in Russia at the time, including publicly active researchers. Note, however, that the plethora of science reporters of that period worked part-time in addition to their main, usually research-related occupation. Therefore, the line between science journalists and active researchers was quite vague. The club was in constant touch with other actors (e.g. club members initiated a series of translations of international popular science bestsellers that were then supported by the Dynasty Foundation as well as the Elementy website).

In 2009, in cooperation with the Commission on Pseudoscience and Research Fraud, the club initiated a broad public discussion that led to the withdrawal of public funding about to be allocated to the production of water filters promoted by the pseudoscientist Victor Petrik. The filters were advertised as a panacea from all the complications of city water supply and their inventor was publicly supported by top members of Russian Academy of Sciences and by Boris Gryzlov, back then the speaker of the lower chamber of the Russian parliament (Nazaretyan, 2010; White, 2010). However, an independent investigation launched by a member of the Commission and supported by many science journalists found that there was no evidence of the efficiency of these filters, as no proper tests had been performed. On the contrary, the filters were contaminating water with heavy metal ions. Civil society celebrated a big victory. Initially, the government planned to implement the filters countrywide, spending the equivalent of $\$ 500$ billion by 2020 , but after the debunking this amount went down to $\$ 5.5$ million by 2017 , and effectively even this money was only partially spent. However, the filters were installed in over 600 public institutions, including schools (Podorvanyk and Alexeeva, 2010).

Corporate science communication in universities and research institutes remained perhaps the largest lacuna in the market. In the Soviet Union, science and education were essentially separate entities. Most research was done in various institutes. Those of the Academy of Sciences were responsible for basic research, while others, supervised directly by the ministries, performed applied research and technology transfer. As for educational organisations, two types existed: universitet and institute. The former were fewer in number and gave basic education, preparing graduates for a research career. The second category provided purely applied training, thus preparing practitioners like teachers, engineers, doctors, etc. All institutes and nearly all universitets were teaching-only, and their academic staff were not involved in any research. For historical reasons this system is very similar to what we see in Germany with its universities and hochschule, as well as various societies of research 
institutes. Thus, Soviet universities were alien not only to their third, but also to their second mission (Scott, 2006). Recall that universities are not only responsible for developing human capital (education-the first mission) and producing new knowledge (research-the second mission), but they must also engage with societal needs and market demands by establishing links with the surrounding socioeconomic environment (the third mission). Today, most universities develop their strategies around these three missions. In the framework of Soviet society, centralised science popularisation functions along with the absence of competitiveness and civil society led to a model where communication offices just did not belong. Research organisations enjoyed funding settled by the government plan and did not need to perform any outreach activities, either for the sake of academic competitiveness or to engage with the public. This status quo remained and prevailed until the late 2000s with a couple of exceptions. Russian research organisations lagged behind in science communication and received a wakeup call much later.

The crisis in the mass media market and abrupt changes in the Russian political course hindered many of the projects discussed above, but their contribution did not slip through the cracks. On the contrary, this decade was a game changer for Russian science communication. The combination of private funding and extensive media coverage put science back on the public radar and brought science communication into the focus of the government.

\section{The empire strikes back (2011-16)}

The 2010s brought serious perturbations with respect to how science communication is sponsored and implemented. With the Russian budget enjoying higher oil and gas prices from the early 2000s (Sonin, 2004), the state finally became a bigger player in science and brought a greater asymmetry in the allocation of power and resources. This period is marked by a tectonic shift in the Russian academic system, which consequently affected science communication.

In 2013, the government initiated a long-expected reform of the Russian Academy of Sciences, accelerating the dismantling of the Soviet-style science management. The same year, a national academic excellence program called Project 5-100 was launched. The project was aimed at improving the position of leading Russian universities in international university rankings and, as a side effect, triggered a wave of important developments in corporate science communication. Bigger goals aided by additional funding allowed the universities to employ experienced and ambitious press officers and science communicators. This movement, however, was complicated by a lack 
of these specialists in the market. As a result, some of the newborn PIOs (public information officers) were former science journalists, others were researchers and lecturers, and yet others were public relations professionals in a broader sense. These people came out of their comfort zone to enter or even create an entirely new profession for the country. Project 5-100 thus became a locomotive of corporate science communication, ensuring that at least a dozen of the top Russian universities established and expanded their public information offices. Among the drivers of this process were the Moscow Institute of Physics and Technology (MIPT), Higher School of Economics (HSE), National University of Science and Technology MISiS, ITMO University in St Petersburg, Tomsk State University, Ural Federal University in Yekaterinburg, and several others.

In turn, the reform of the Russian Academy of Sciences (Clark, 2013) changed drastically an institution that was once famous worldwide as the flagship of Soviet science. Unlike European or American academies that are mostly expert bodies or honorary clubs, the Soviet (and later the Russian) Academy of Sciences was a powerful structure operating numerous research institutes across the country and managing a big chunk of state science funding. After the reform, the institutes and the funding fell under the control of a newly established Federal Agency for Scientific Organizations (FASO), and later under the direct control of the Ministry of Science, while the Academy started to function as an elite researchers' club with generous lifelong stipends. FASO stimulated competitiveness and demanded higher efficiency indicators from the institutes. Other factors, such as the establishment of the Russian Science Foundation (RSF) in 2013, fuelled competition for funding and other resources among Russian researchers. As a whole this setup gave institutes an impetus to start hiring public information officers, albeit with less vigour than universities. A recent assessment of the communication function in more than 1,500 institutes and 850 universities demonstrated that around 40 per cent had at least a communication representative (Russian Association for Science Communication, 2016). These figures are still low, but, importantly, in recent years there has appeared a group of organisations (mostly universities) that lead the pack. It should be mentioned, however, that for the institutes the distribution is quite even among fields of sciences and geography, while universities suffer strongly from the so-called Matthew effect $^{2}$ - a huge gap between the leaders from Project 5-100 and the weaker group of former instituts is observed.

2 The Matthew effect can be best summarised by the adage 'the rich get richer and the poor get poorer'. 
This newly born community of science PIOs was given an additional stepping-stone to move forward. In 2014, the Russian Venture Company (RVC), a key government fund of funds, ${ }^{3}$ launched a long-term project named Communications Laboratory intended to build bridges between researchers, journalists and PIOs. Heavily involved in the process of building the national science and innovation ecosystem, RVC was among the first governmentbacked structures to realise the existence of serious communication barriers in Russian science. The immediate goal of the Communications Laboratory was to organise educational and networking activities for researchers and communication professionals, as well as undertake some initial research on the state of science communication in Russia. The project stood out by virtue of its international outlook and deliberate reliance on the Western culture and terminology of science communication. As an example, inspired by Eurekalert and AlphaGalileo, Russia's first science news distribution website Otrkytaya nauka (Borissova and Koenig, 2017) was launched in the framework of the project in 2015.

The fact that some science journalists became eager to switch to a PIO job came from the changing situation in the mass media. In 2013-14 nearly all independent media outlets were put under some form of governmental control (Meduza, 2016), which delivered a blow to the already-dying freedom of speech (Kovalev, 2017). As a result, general interest mass media virtually lost their say in the field of science. As the public interest in science endured in Russian society (Vaganov, 2016), a number of reporters left their general interest magazines and started independent popular science websites that virtually took the place of the Soviet-era science magazines. Digital science magazines are, indeed, quite popular today. The leaders are Popular Mechanics (2 million unique visitors monthly, according to Liveinternet), National Geographic Russia (1.4 million unique visitors monthly, according to Rambler) and $N+1$ (1.3 million unique visitors monthly, according to Rambler). The lack of competition from traditional print media, radio and TV where science is scarcely and poorly represented helps them attract relevant audiences and resources.

Modern Russian digital science magazines are technologically advanced and appealing to younger audiences-for example, through their use of handy mobile versions and mobile apps. A solid scientific background combined with digital acumen has inspired some of these magazines to explore international markets. For example, www.nmas1.org, a Spanish-speaking branch of the

3 A fund of funds (FOF) is an investment strategy of holding a portfolio of other investment funds, rather than investing directly in stocks, bonds or other securities. 
Russian $N+1$, entered the top 5 most-read Spanish-speaking science media. Digital science magazines focus on research news rather than science policy and their reporters increasingly aspire to become part of the global science journalism community. The flipside here is that these outlets mostly rely on state and/or corporate funding. In other words, a good share of their financial support comes either from the Ministry of Science and Education or from leading Russian universities and research centres that influence the agenda.

The government control of science communication brought other dramatic changes. In May 2015, the entire research community in Russia was hit by a shockwave: all the grant programs of the Dynasty Foundation were discontinued along with the foundation itself as a consequence of it being labelled a foreign agent by the Russian government. This news caught Russian scientists flat-footed and rumbled over the world (Pokrovsky, 2015). The biggest private founder of science and science popularisation was kicked out of the game for reasons which people still speculate about. It is not farfetched, however, to suggest that the Russian government saw political risks associated with the activity of the foundation. Some criticisms were heard earlier that the foundation politicised Russian science as it was providing financial support only to those researchers who voiced views against the government. After the Dynasty Foundation was forced to shut down, some of its projects were taken over by the much smaller independent Evolution foundation, which became the main body training semi-professional science lecturers (Rudneva, 2018). The ousting of independent funders meant that the government was preparing to enter the market itself with significant resources and its own view of how things should be done.

A good example of how the government re-entered the field of science communication is its sudden interest in science museums, which was, quite ironically, stirred by the Dynasty Foundation's museum program. Being the only grant program for science museums and centres, the closure of the Dynasty Foundation certainly hit hard. Nevertheless, it did set the wheels in motion. Despite persistent financial problems, the revitalisation of Russian science and natural history museums caught the attention of government officials even before the closure of the Dynasty Foundation. In April 2010, Russia's then president Dmitry Medvedev instructed the government to develop a new museum concept based on the Polytechnic Museum and its vast collections. This decision turned into an almost decade-long quest. Modernisation involved a massive reconstruction of the historic building by the Japanese architect Jun'ya Ishigami, a sweeping revision of all methodological and conceptual approaches, and major structural changes in how the museum was governed and operated. The very idea was largely lobbied for by Anatoly Chubais, an influential politician and former deputy prime minister in Boris Yeltsin's administration. 
The complexity of the project was reinforced by a relatively modest overall professionalism in the field of science and technology museums in Russia at that time. Museum curators and specialists in Russia mostly came from arts backgrounds and had no scientific or technical background, let alone any understanding of how to create world-class science museums from the ruin. The widespread financial and political support that surrounded the modernisation process, however, assisted the development of the museum. By 2018 it was fair to say that the Polytechnic Museum had made enormous progress, both in terms of conceptual thinking and physical infrastructure.

According to the personal account of Natalia Sergievskaya, the deputy director of the Polytechnic Museum, the last 10 years have dramatically raised the bar on professionalism in the field of science museums and centres. International mobility and exchange made it possible for Russian museum experts to get access to best museum practices overseas. However, Sergievskaya acknowledges that the situation is far from balanced when it comes to Russia as a whole. Too much depends on political support and only a chosen few achieve it. This in part explains why the Moscow Polytechnic Museum, despite its apparent march towards a successful relaunch, has not excelled in community building. For example, the Russian Association of Science and Technology Museums (AMNIT), which is led by the Polytechnic Museum, currently remains in a state of dormancy. The sheer gap between the Polytechnic Museum and other regional science museums has made any well-meaning exchange of practices improbable. Nevertheless, through trial and error, the Polytechnic Museum is moving towards a scheduled opening in 2021 and hopes are high that after the launch it will provide more methodological support to regional counterparts.

Popular science events were also invaded by the government, although as we show later several private initiatives did make an enormous difference during this period. From the late 2000s and early 2010s, several state corporations, such as the State Atomic Energy Corporation (Rosatom) and the Russian Nanotechnology Corporation (Rusnano), fiercely began supporting popular science events. In 2008, Rosatom sponsored the creation of a network of Information Centers for Atomic Energy (ICAE) that were assigned the mission of science popularisation with a special emphasis on atomic energy. The centres currently exist in 17 Russian cities as well as in Minsk and Astana. Public events organised by ICAE are characterised by original and humorous formats, in part due to its key target audience-kids. For instance, the event called Trials Against Superheroes features a dramatised discussion where a prosecutor and lawyer try to prove whether a comic superhero violates the laws of physics. Rusnano, in turn, regularly supports its own series of popular science events and other activities, but with a focus on nanomaterials and technology. 
In 2011, with increased support from the government, the science festival NAUKA $0+$ attained the status of an all-Russian event with dozens of participating cities and hundreds of organisations involved. It had been organised since 2006 by the Moscow State University, and in 2017 the overall outreach of the festival was calculated to be 2.5 million people visiting around 6,000 events, organised throughout the year in 80 regions under the umbrella of the All-Russian Festival of Science. Despite this national conquest, the central stage for the event remains in Moscow, where each October the festival attracts the most visitors. For instance, during the 2018 edition, the Moscow event was attended by 870,000 people. A distinctive feature of the AllRussian Festival of Science is that each year the organising committee selects several central regional locations, where the event adopts a more centralised and ambitious character. Usually this role is taken by relatively big Russian cities, such as Krasnoyarsk or Murmansk.

The renewed role of the government in science popularisation was additionally accentuated by the establishment in 2014 of a prestigious award Za vernost nauke [For Commitment to Science], also sometimes referred to as 'True Science'. This symbolic initiative was launched by the Russian Ministry of Science and Education to honour popularisers in all fields, from science journalism to popular events.

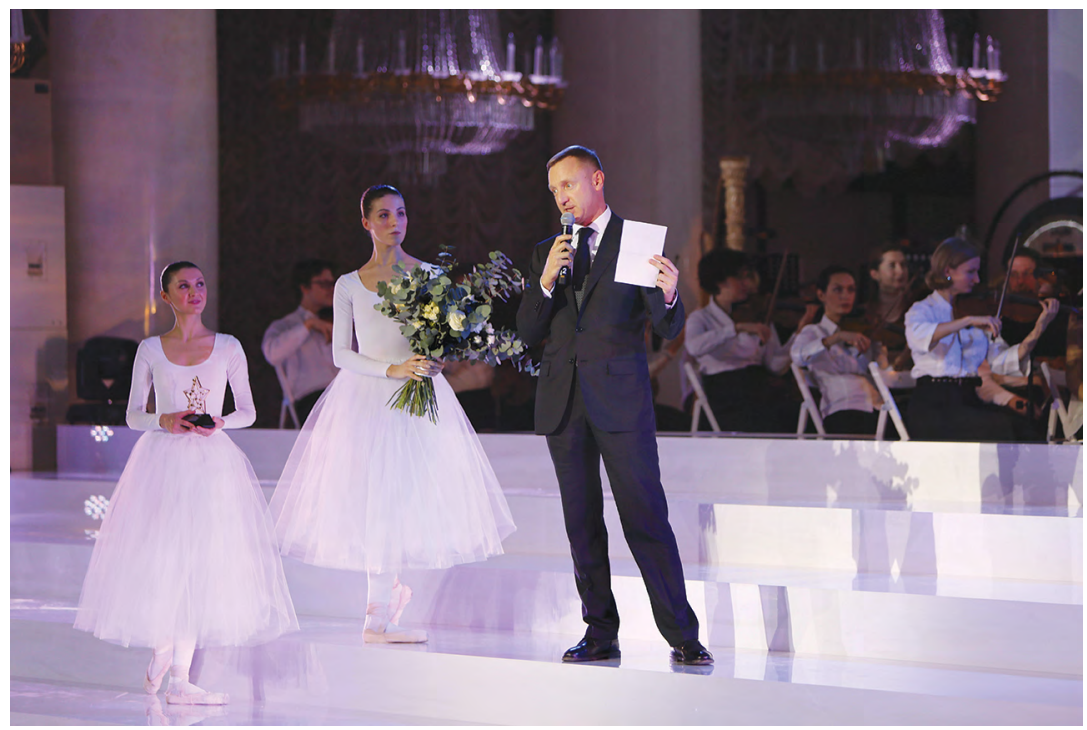

Figure 30.3: Former Russian Minister of science and education Dmitry Livanov at the ceremony of the True Science award.

Source: Maria Olendskaya (used with permission). 
Popular science events in Russia took a curious twist in the early 2010s when a German popular science project called Science Slam ${ }^{4}$ took off in Russia. In retrospect, the success of Science Slam might be attributed to its informal and cheerful approach to science communication, which contrasted strongly with events organised by universities, museums and other learned societies in Russia. Public lectures were mostly given by academic scientists whose views on popularisation were influenced by the patronising image of Soviet science propaganda. In a striking contrast, Science Slam usually took place in bars and rock clubs (Zhitkova and Grishin, 2018). No surprise that they felt like a breath of fresh air, especially to younger audiences. Soon dozens of Russian cities embraced the idea, using local bars and clubs as a venue for this unorthodox format. In 2016, the scope of the movement became so staggering that a separate Science Slam Association was established. By 2018 the network included 38 cities, with more than 150 events and over 45,000 visitors.

The format is constantly evolving and is being adopted by companies, universities and even schools. Corporate Slams, in turn, are giving rise to thematic variations. Be it materials science, medicine or computer technologies, events for each of these subject fields have been organised at some point, all under the same brand and franchise. Notably, the Russian Nanotechnology Corporation (Rusnano) has been one of the biggest sponsors of this unfolding bottom-up movement. The corporatisation of Science Slam and several other similar projects, such as Smart Moscow, are a trend in Russia. Finally, a TV show inspired by Science Slam appeared on national television despite the otherwise weak presence of science on air.

Of all the activities described in this chapter, science communication training is perhaps one of the most recent phenomena. As discussed in the previous sections, in the 1990s Russian scientists were left out of the massive attempt of making every scientist a populariser of his or her own work, which did take place in the 1990s in the UK, for example, and presumably some other European countries (Bauer and Gregory, 2007). The idea that researchers should consider public communication as part of their professional duties was not around in Russia until recently and is far from being fully embraced even now. This realisation coincided with the advent of PR-oriented science communication in major Russian universities and other research organisations. Therefore, while in Europe the integration model of science communication (where public communication is an integral part of scientists' jobs) anticipated the specialisation model (where professional communicators are needed to

4 A Science Slam is a scientific talk where scientists present their own research work in a given time frame (usually 10 minutes) in front of a non-expert audience in an informal setting of a bar or a club. 
serve as intermediaries between scientists and the audience) (Davies and Horst, 2016), in Russia both were rediscovered at roughly the same time. This produced a noticeable impact on the evolution of science communication training in Russia. While graduate and postgraduate communication training was considered a routine practice elsewhere, in Russia no such training was widespread until the mid-2010s, with several exceptions.

Russia's first science journalism master's degree was launched only in 2013 at the Moscow State Institute of International Relations (MGIMO) and was part of the government takeover of science communication. The initiative was backed by the Russian Academy of Science, the Moscow State University and the Ministry of Science and Higher Education. Essentially, it was the first step towards the formalisation of science journalism education, which at the time was only represented by various summer schools and short-term seminars. In 2014, the Moscow State University (MSU) decided to catch up and followed with another master's degree in science journalism and communication. Despite having a strong lobby, neither of the programs quite took off. The MGIMO program came to an end in 2015 and never made another admission, while the MSU program was put on hold later. In parallel to these developments, Saint-Petersburg State University, the second largest university in Russia, decided to launch another master's degree in popular science journalism in 2014. Based at the Faculty of the History of Journalism, the program had a more consolidated theoretical foundation. However, this orientation towards theoretical and historical aspects (rather than more practical aspects of modern journalism) was and is both the strength and weakness of the program.

\section{Raising the bar on professionalism (2016-present)}

The government attempt to take control over science communication training did not entirely pay off. What unified the higher education programs described above was their reliance on science journalism training as opposed to the broader domain of public communication of science. The very term 'science communication' was not widely used to refer to public communication of science and technology until the early 2010s, although it is hard to define any strict boundaries. Instead, the term was used perhaps more frequently in the context of scholarly communication. This balance changed dramatically with the unfolding of the RVC's Communications Laboratory project, which disseminated the public dimension of the term as well as a broader view of science communication as a professional field. 
An attempt to launch a degree (BA this time) on this new premise was made in 2015 by the Moscow Polytechnic University, but it did not fly high either. Although the project was supported by RVC's Communications Laboratory and featured prominent Russian science journalists and communicators, the program was tormented by political winds at the university. Two years after the launch, the program management left the university, depriving the degree of its science and technology core. The students were transferred to a general $\mathrm{PR}$ and advertising track, thus rendering the project a failed experiment.

Since 2016, a new cascade of educational programs has been set in motion. Many of them were built on the basis of science communication as a separate and broad profession, encompassing all possible formats and variations of public engagement with science. These ideas were in part brought to Russia from overseas by internationally active members of the Communications Laboratory. In 2016, the race to build a full-blown science communication degree was joined by ITMO University, a top technical university located in St Petersburg and leading member of the abovementioned 5-100 Project. The new master's degree claimed an all-embracing view of science communication from science journalism and PR to science museums and visualisation. Most of the courses were designed specifically for the program and relied on job market leaders rather than academics. The program has already produced several waves of graduates. It is fair to say that among Russian higher education institutions, ITMO University has made the biggest bet on science communication research and education. On the sidelines of the master's degree, in 2016 ITMO University launched the first Russian MOOC on the same subject and continues to make periodic launches to the present day. Apart from the science communication degree, in 2018 the university launched a new English-speaking master's degree in art and science.

Numerous educational programs continue to appear at different levels, from summer schools to intensive seminars. Several part-time courses deserve to be mentioned (some appeared earlier than 2016), such as courses at the Moscow Higher School of Economics, Novosibirsk State University and the Moscow Institute of Physics and Technology.

An array of schools and short-term trainings also exists outside the universities, such as the Science and Journalism Summer School, which first appeared in 2011 and flourished in the years following. Traditionally organised as part of a large educational summer camp at the recreational compound of the Joint Institute for Nuclear Research, the school received much acclaim and support among leading scientists and journalists. Until now, it remains one of the most massive and oldest functioning science journalism schools in Russia. In higher education, the latest development occurred in 2018 with 
Peter the Great St Petersburg Polytechnic University declaring the launch of another master's degree in public relations in the field of science and technology. It is too soon to make any judgements about the program itself, but its announcement marks another step towards the institutionalisation of science communication training in Russia.

The appearance of higher education programs was instrumental to a wider appreciation for science communication as a research field. Russian authors have been virtually absent from the international research literature on science communication, but the abovementioned educational programs have begun to build a core of communication practitioners who have made a switch towards research, or social scientists who chose science communication as their focus of interest. Still, research on science communication and engagement in Russia is a long way from becoming solid and internationally recognised. Most research projects were started recently and are still in progress or in the publishing phase. The Higher School of Economics (HSE) and the European University at St Petersburg are among the strongest research centres for social sciences in Russia and perform some studies of interest to science communicators.

HSE, along with Levada-centre, is a major provider of data on scientific literacy and public attitudes to science in Russia. HSE annually publishes the Science and Technology Indicators in the Russian Federation Higher School of Economics (HSE). This research repeatedly shows a certain degree of respect for the profession of scientist among the Russian population. Between 2003 and 2016, around one-third of Russians mentioned that they wanted their child to become a researcher, with a record high of 43 per cent in 2009 and a record low of 26 per cent in 2014. The number of people praising both the level of Russian science and the amount of its funding gradually grew from 1997 to 2016 . In 1997 only 40 per cent of Russians said in their responses that research in Russia is stronger or at the same level as in developed countries, but by 2016 this figure grew to 58 per cent. In 1997 only 9 per cent of Russians thought that science funding is sufficient or surplus, but by 2016 this figure reached 44 per cent (Chernovich et al., 2016).

Little is known about public trust in science. The latest HSE data manifests strong support for both positive and negative notions about science and technology (Chernovich et al., 2016). Up to 75 per cent agree that they 'make our life healthier, easier and more comfortable' and 'future generations will have more opportunities thanks to science and technology'. But nearly the same percentage of the population thinks that 'science and technology change our life too fast' and 'advances in science and technology can lead to negative consequences for health and environment'. Another popular 
counter-scientific notion states that 'nowadays people draw too much attention to advances in science and technology and too little attention to the spiritual side of life'. Generally, there is no organised system of research in the field of public understanding of science, or any solid empirical work aimed at testing various approaches to science communication. This is, however, not a special case, but rather a manifestation of a generally poor institutionalisation of science and society studies in Russia.

The process of self-identification with the new profession and the international community was enhanced by the establishment of the Russian Association for Science Communication AKSON in 2016. It was established with no institutional support by five independent communication specialists: Alexandra Borissova (TASS Russian News Agency), Elena Brandt (Moscow Institute of Physics and Technology), Ekaterina Ivanova ('Teorii i Praktiki), Elena Zemtsova (Moscow Polytechnical University) and Dmitry Malkov (ITMO University). ${ }^{5}$ Since then, the association has grown to more than 200 members from all over Russia and CIS countries, ${ }^{6}$ bringing together both PIOs and science journalists. AKSON promotes and defends the interests of the professional community and engages in periodic networking and educational activities. Supported by RVC, AKSON gives out the annual Communication Lab award, which acknowledges prominent achievements in corporate science communication. Since 2018, AKSON operates the national competition for the European Science Writer of the Year award in cooperation with Rusnano. Both awards are presented during the annual Forum of Russian Science Communicators that has become a major networking site for Russian science PIOs and journalists.

Despite clear progress with educational programs and community building, it is premature to say that science communication is fully institutionalised in Russia. Another important feature is missing-namely, the inclusion of science communication in state policy. To this day, Russia has no separate state policy on science communication or engagement. However, several references are included in a key document that was officially published in December 2016: the Strategy for Development of Science and Technology (Russian Federation, 2016).

5 Affiliations are listed as of August 2016.

6 The Commonwealth of Independent States (CIS) was formed following the dissolution of the Soviet Union in 1991. It has nine members, plus two founding non-members. 


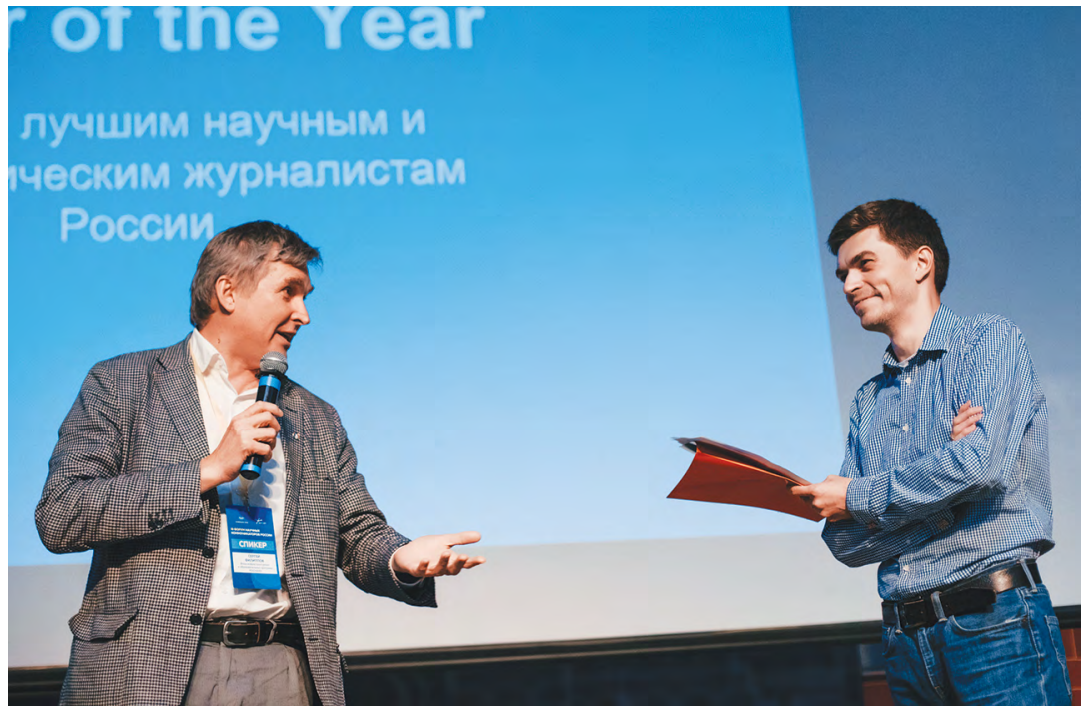

Figure 30.4: Third Annual Conference of the Russian Association for Science Communication in 2018. Announcement of the inaugural winner of the Russian Sci\&Tech Writer of the Year award: Shamil Troyanovsky.

Source: Shamil Troyanovsky (used with permission).

Sadly, the strategy barely addresses the lack of understanding of any science and society relationship in Russia. With respect to science communication, the document assumes the deficit model in urging the construction of an efficient system of communication in the field of science, technology and innovation to ensure the growth of economic and social susceptibility to innovation and high-tech entrepreneurship. The strategy additionally calls for adjusting the information policy so as to develop a technological culture and social susceptibility to the popularisation of important scientific and technological achievements, as well developing the role of outstanding researchers, engineers and entrepreneurs in ensuring the socioeconomic progress of the country. The conclusion is that the strategy must provide for the growth of influence of science on the Russian society.

Curiously enough, one sentence from the document hints at potential plans to step out from the deficit model and move towards enabling conditions for mutual influence of science and society and engaging the society by providing various feedback loops. It calls for 'conditions that contribute to reciprocal influencing between science and society by involving the society in shaping demand for the research outcomes' (Russian Federation, 2016). However, the gap between the deficit model understanding and these flirtations with participatory engagement is not bridged by any comprehensive 
recommendations or plan of action. Neither does the strategy call for the much-desired intensification of research in public communication of science. So far, these statements seem to be just buzzwords rather than real intentions. The general observation is that state priorities are mostly agenda-driven rather than evidence-based, and that the current strategy is poorly informed on available evidence and does not encourage any further research. Attempts are currently being made by the community to push for a full-blown science communication strategy, but they are nowhere near getting traction.

\section{Acknowledgements}

The authors extend their gratitude to Olga Orlova, Natalia Sergyievskaya, Lubov Strelnikova, Irina Aktuganova, Arina Pushkina, Larisa Bakulina, Andrey Kozhanov, Nikolay Avanesov and Alina Koroleva. Dr Alexandra Borissova expresses her special thanks to German Chancellor Fellowship (Alexander von Humboldt Foundation, Germany) and Professor Alexander Gerber (Rhine-Waal University, Germany) for their kind help and support during her research stay. Without it this work would not be possible.

\section{References}

Andrews, J. (2003). Science for the masses: The Bolshevik state, public science, and the popular imagination in Soviet Russia, 1917-1934. Texas A\&M University Press.

Baldscientist. (2013, 10 February). The Sagan Effect. Retrieved from baldscientist. wordpress.com/2013/02/10/the-sagan-effect/.

Bauer, M. and Gregory, J. (2007). From journalism to corporate communication in post-war Britain. In M. Bauer and M. Bucchi (eds), Journalism, science and society: science communication between news and public relations (pp. 33-52). Routledge Studies in Science, Technology and Society. Abingdon, UK: Routledge. doi.org/ $10.4324 / 9780203942314$.

Borisova, A. and Koenig, J. (2017). Opit na nacyonalnom yazike [Experience in the national language]. Troitsky variant (online). Retrieved from www.trv-science. ru/2017/04/11/opyt-na-nacionalnom-yazyke/.

Borisova, A. O. and Malkov, D. V. (2018). Five faces of Russian science communication. Spokes Magazine. Retrieved from www.ecsite.eu/activities-and-services/news-andpublications/digital-spokes/issue-39\#section=section-indepth\&href=/feature/ depth/five-faces-russian-science-communication.

Burova, M. (2014). Interview with Anton Sharypov. Retrieved from www.sobaka.ru/ $\mathrm{krsk} /$ city/city/30986. 
Carnegie Medal for Philanthropy. (2013). Dmitry Zimin: Russian for philanthropy. Retrieved from www.medalofphilanthropy.org/dmitry-zimin-russian-philanthropy/.

Chernovich, E., Ditkovsky, K., Fridlyanova, S., Fursov, K., Gokhberg, L., Gorodnikova, N., Kotsemir, M., Kuznetsova, I., Lukinova, E., Martynova, S., Polyakova, V., Ratay, T., Rosovetskaya, L., Sagieva, G. and Sergeeva, V. (2016). Science and Technology Indicators in the Russian Federation: Data Book. Moscow: National Research University Higher School of Economics. . Retrieved from www.hse.ru/ data/2018/02/08/1162213715/Science_and_Technology_Indicators_in_the_ Russian_Federation_2016.pdf.

Clark, F. (2013). Reforming the Russian Academy of Sciences. The Lancet, 382, 1392-93. doi.org/10.1016/S0140-6736(13)62142-X.

Davies, S. R. and Horst, M. (2016). Science communication: Culture, identity and citizenship. UK: Palgrave Macmillan. doi.org/10.1057/978-1-137-50366-4.

Dynasty Foundation. (n.d.). Public lectures of the Dynasty Foundation. Retrieved from web.archive.org/web/20190214221207/http://www.dynastyfdn.com/programs/ popular/lections.

Fishman A. M. (2016). Argumenty I Facty [Arguments and Facts]. The Great Russian Encyclopedia, vol. 2. Moscow.

Graham, L. and Dezhina, I. (2008). Science in the New Russia: Crisis, aid, reform. Indiana University Press.

Kovalev, A. (2017, 25 March). In Putin's Russia, the hollowed-out media mirrors the state. The Guardian. Retrieved from www.theguardian.com/commentisfree/2017/ mar/24/putin-russia-media-state-government-control.

Kukulin, I. (2017). Periodicals for Engineers: Soviet Popular Science Journals and the Shaping of the Late-Soviet Scientific and Technical Intelligentsia’s Interests. Novoe Literaturnoe Obozrenie, 145.

Litvak, N. (2008). Information society: Permanent evolution. Moscow: Kolos Press.

Meduza. (2016, 18 March). 12 redakzy za pyat let Razgony, blokirovki, uvolnenia glavredov, kak vlast reformirovala rynok SMI [12 editorial offices in five years: Crackdowns, blockings, dismissals of editors-in-chief: how government reformed the mass media market]. Meduza.io. Retrieved from www.meduza.io/ feature/2016/05/17/12-redaktsiy-za-pyat-let.

Milanovich, B. (1998). Income, inequality, and poverty during the transition from planned to market economy (pp. 196-202). Washington DC: The International Bank for Reconstruction and Development and The World Bank.

Nauka i Zhizn. (1977). Obshestvu Znanie 30 Let [The Znanie Society Turns 30]. Nauka i Zhizn, (5), 26. Izdatelstvo Pravda, Moscow.

Nazaretyan, K. (2010). Petrikgate. Saint Petersburg Branch of the Russian Humanist Society. Retrieved from www.humanism.su/en/articles.phtml?num=000084. 
Palshina, I. (2010). Samiy krupniy v Rossii muzei zanimatelnoi nauki nahodtsiya v Irkutske [The Biggest Popular Science Museum in Russia is Located in Irkutsk]. Argumenty I Facty, 43. Retrieved from irk.aif.ru/science/science_details/78338.

Panchenko, A. (2018). The Age of Aquarius» for the Builders of Communism: New Age Culture in Late Soviet Society and the Problem of «Periods of Change. Novoe Literaturnoe Obozrenie, 149.

Podorvanyuk, N. and Alexeeva, O. (2010, 7 July). Voda iz filtra Petrika opasna dlya zdoroviya [Water from Petrik's filters is dangerous for heath]. Gazeta.ru. Retrieved from www.gazeta.ru/science/2010/07/07_a_3395369.shtml.

Pokrovsky, V. (2015, 9 July). Russia's only private science funder closes its doors. Science magazine. Retrieved from www.sciencemag.org/news/2015/07/russias-onlyprivate-science-funder-closes-its-doors. doi.org/10.1126/science.aac8829.

Rambler Top 100. (n.d.). Retrieved from top100.rambler.ru/.

Ria Novosti. (2013). Interview with Viktor Sadovnichiy. Ria.ru. Retrieved from www. ria.ru/20131007/968271833.html.

Rudneva, V. (2018). Talking about the Big Bang: An exploratory study of how Russian science communicators use social media. Coursework material, Media and Communications Studies Programme, Department of Media Studies, Stockholms Universitet. Retrieved from www.diva-portal.org/smash/get/diva2: 1212857/FULLTEXT01.pdf.

Russian Association for Science Communication. (2017). First report on the professionalisation of science communication in Russia. Russian Association for Science Communication (AKSON) (online). Retrieved from akson.science/ news/2017/08/14/opublikovany-rezultaty-issledovanija-professionalizacijanauchnoj-kommunikacii-v-rossii/.

Russian Federation. (2016). Scientific and Technological Development Strategy of the Russian Federation. Retrieved from online.mai.ru/StrategySTD\%20RF.pdf.

Russian Venture Company. (2016). Analytical report on Russian science museums and centres. RVC official website. Retrieved from www.rvc.ru/upload/iblock/868/ museums_study.pdf.

Sapun, A. (2016). Istoria razvitia internet-SMI v Rossiye [History of online mass media in Russia]. Dni.ru. Retrieved from www.dni.ru/academ/2016/8/1/ 347408.html.

Scott, J. (2006). The mission of the university: Medieval to postmodern transformations. The Journal of Higher Education, 77(1) (online). doi.org/ 10.1353/jhe.2006.0007.

Sonin, K. (2004). The unbearable lightness of petrodollars. Russia in Global Affairs, 2, 94-100. 
State Legal Information System. (2015). Ukaz Prezidenta Rossiskoy Federazii ot 11.12.2015 No. 617 "O sozdanii Obsherossiskoy obshesvenno-gosudarstvennoy organizatsii Rossiskoye obshestvo Znanie” [Decree of the President of the Russian Federation of 11.12.2015 No. 617 'On the Creation of All-Russian Public Educational Organisation Russian Society Znanie’]. Retrieved from publication. pravo.gov.ru/Document/View/0001201512110006.

Vaganov, A. (2016). Evolution of forms of science popularisation in Russia: 18th21st centuries. Science. Innovation. Education, 3(21).

White, G. (2010, 5 March). Russian inventor has friends in Kremlin, but skeptics outside it. The Wall Street Journal. Retrieved from www.wsj.com/articles/SB1000 1424052748704187204575101510173019130.

Yakovenko, I. (2012, 30 August). Rynok nauchno-populyarnich jurnalov. Analitichesky obzor [Market of popular science magaizes. An analytical review]. Nazionalnaya tirazhnaya sluzhba. Retrieved from www.pressaudit.ru/rynoknauchno-populyarnyx-zhurnalov-analiticheskij-obzor/.

Zhitkova, V. and Grishin N. (2018). Bitva botanikov: skolko prinosyat komedyinie shou s uchenimi [Battle of geeks: How much money shows with scientists bring]. Rbc.ru. Retrieved from www.rbc.ru/own_business/26/04/2018/5ae052a19a79 47223 c1a8cbd.

Znanie Society. (n.d.). History of the Znanie Society. Retreived from www.znanie. org/OZR/history.htm.

\section{Timeline}

\begin{tabular}{|l|l|l|l|}
\hline Event & Name & Date & Comment \\
\hline $\begin{array}{l}\text { First interactive } \\
\text { science centre } \\
\text { established. }\end{array}$ & $\begin{array}{l}\text { Experimentary } \\
\text { (Irkutsk) }\end{array}$ & 2005 & $\begin{array}{l}\text { Experimentary was created by the } \\
\text { Siberian branch of the Russian } \\
\text { Academy of Sciences inspired by } \\
\text { the San Francisco Exploratorium }\end{array}$ \\
\hline $\begin{array}{l}\text { First national (or } \\
\text { large regional) } \\
\text { science festival. }\end{array}$ & $\begin{array}{l}\text { NAUKA 0+ } \\
\text { established by } \\
\text { Lomonosov } \\
\text { Moscow State } \\
\text { University }\end{array}$ & 2005 & $\begin{array}{l}\text { Has grown from a local event attended } \\
\text { by 20,000 people, to an all-Russian } \\
\text { event with dozens of participating cities } \\
\text { and 2.5 million participants at around } \\
\text { 6,000 events }\end{array}$ \\
\hline $\begin{array}{l}\text { An association of } \\
\text { science writers } \\
\text { or journalists or } \\
\text { communicators } \\
\text { established. }\end{array}$ & $\begin{array}{l}\text { Russian } \\
\text { Association } \\
\text { for Science } \\
\text { Communication } \\
\text { (AKSON) }\end{array}$ & 2016 & $\begin{array}{l}\text { AKSON has more than 200 members } \\
\text { from Russia and CIS countries. } \\
\text { It brings together both PIOs and } \\
\text { science journalists }\end{array}$ \\
\hline $\begin{array}{l}\text { First university } \\
\text { courses to } \\
\text { train science } \\
\text { communicators. }\end{array}$ & $\begin{array}{l}\text { Moscow State } \\
\text { Institute of } \\
\text { International } \\
\text { Relations, MSc } \\
\text { in science } \\
\text { journalism }\end{array}$ & 2014 & $\begin{array}{l}\text { This focuses on science journalism } \\
\text { rather than science communication. } \\
\text { It does not provide training for science } \\
\text { communicators, but is the first master's } \\
\text { degree to formally include science } \\
\text { communication }\end{array}$ \\
\hline
\end{tabular}




\begin{tabular}{|c|c|c|c|}
\hline Event & Name & Date & Comment \\
\hline $\begin{array}{l}\text { First master's } \\
\text { students in science } \\
\text { communication } \\
\text { graduate. }\end{array}$ & $\begin{array}{l}\text { ITMO University, } \\
\text { MSc in Science } \\
\text { Communication } \\
\text { is considered } \\
\text { to be Russia's } \\
\text { first fully } \\
\text { fledged degree } \\
\text { on science } \\
\text { communication }\end{array}$ & 2018 & $\begin{array}{l}\text { The degree claims an overarching } \\
\text { view of science communication from } \\
\text { science journalism and PR to science } \\
\text { museums and visualisation. Most of } \\
\text { the courses were designed specifically } \\
\text { for the program and relied on job } \\
\text { market leaders, rather than academics }\end{array}$ \\
\hline $\begin{array}{l}\text { First national } \\
\text { conference } \\
\text { in science } \\
\text { communication. }\end{array}$ & $\begin{array}{l}\text { Russian Science } \\
\text { Communicators } \\
\text { Forum }\end{array}$ & 2016 & $\begin{array}{l}\text { Organised by AKSON and since } 2016 \\
\text { it has become a major networking } \\
\text { site for Russian science PIOs and } \\
\text { journalists }\end{array}$ \\
\hline $\begin{array}{l}\text { First significant } \\
\text { initiative or report } \\
\text { on science } \\
\text { communication. }\end{array}$ & $\begin{array}{l}\text { Communications } \\
\text { Lab Project } \\
\text { (Russian Venture } \\
\text { Company) }\end{array}$ & 2014 & $\begin{array}{l}\text { Launched to bridge the gap between } \\
\text { scientists, media professionals and } \\
\text { public information officers. A first } \\
\text { national overview of the development } \\
\text { of science communication in Russia }\end{array}$ \\
\hline $\begin{array}{l}\text { First significant } \\
\text { radio programs on } \\
\text { science. }\end{array}$ & $\begin{array}{l}\text { Granit nauki } \\
\text { [Granite of } \\
\text { Science] }\end{array}$ & 1997 & $\begin{array}{l}\text { Broadcast by radio station Echo of } \\
\text { Moscow owned by Gazprom-media. } \\
\text { Won a True Science award in } 2016 \\
\text { from the Ministry of Science }\end{array}$ \\
\hline $\begin{array}{l}\text { First significant } \\
\text { TV programs on } \\
\text { science. }\end{array}$ & $\begin{array}{l}\text { Ochevidnoe- } \\
\text { neveroyatnoe } \\
\text { [Obvious- } \\
\text { unbelievable] }\end{array}$ & 1973 & $\begin{array}{l}\text { Started by a prominent science } \\
\text { populariser Sergey Kapitsa and lasted } \\
\text { until his death in } 2012 \text {. Since then } \\
\text { there is no dedicated science TV } \\
\text { program on any major TV channel }\end{array}$ \\
\hline $\begin{array}{l}\text { First awards } \\
\text { for scientists or } \\
\text { journalists or } \\
\text { others for science } \\
\text { communication. }\end{array}$ & $\begin{array}{l}\text { True Science } \\
\text { award was } \\
\text { established by } \\
\text { the Ministry of } \\
\text { Science and } \\
\text { Education }\end{array}$ & 2014 & $\begin{array}{l}\text { True Science does not cover the } \\
\text { work of PIOs or individual science } \\
\text { journalists, but celebrates the } \\
\text { best science media, radio and TV } \\
\text { programs and science popularisers }\end{array}$ \\
\hline
\end{tabular}

\section{Contributors}

Dr Alexandra Borissova is the president of the Russian Association of Science Communicators AKSON and supervisor of Russia's first MSc in science communication at ITMO University in St Petersburg.

Dmitry Malkov is the founder of the Center for Science Communication at ITMO University in St Petersburg, and vice-president for international relations of the Russian Association of Science Communicators AKSON. 
This text is taken from Communicating Science: A Global Perspective, edited by Toss Gascoigne, Bernard Schiele, Joan Leach, Michelle Riedlinger, Bruce V. Lewenstein, Luisa Massarani and Peter Broks, published 2020 by ANU Press, The Australian National University, Canberra, Australia.

doi.org/10.22459/CS.2020.30 